\title{
Failure of Energy Mega-Projects in Chile: A Critical Review from Sustainability Perspectives
}

\author{
Claudio A. Agostini ${ }^{1}$, Carlos Silva ${ }^{2}$ and Shahriyar Nasirov ${ }^{2, *}$ \\ 1 School of Government, Universidad Adolfo Ibañez, Avenida Diagonal Las Torres 2640, Peñalolén, \\ Santiago 7941169, Chile; claudio.agostini@uai.cl \\ 2 Facultad de Ingeniería y Ciencias, Universidad Adolfo Ibañez, Avenida Diagonal Las Torres 2640, Peñalolén, \\ Santiago 7941169, Chile; c.silva@uai.cl \\ * Correspondence: shahriyar.nasirov@uai.cl; Tel./Fax: +56-2-2331-1777
}

Received: 28 March 2017; Accepted: 14 June 2017; Published: 20 June 2017

\begin{abstract}
A number of successive energy crises over the last decade due to the lack of a balanced investment planning in the energy sector in Chile has led to a strong dependence on external sources and also doubled energy prices in the country, thus posing a significant challenge to the local economy. With the purpose of reaching long-term goals while simultaneously addressing short-term urgencies, Chile seeks to build a consistent and integrated energy policy in order to attract investment in the sector. Despite an overall attractive investment climate and encouraging market conditions in the country, the energy sector has been adversely affected, in particular, by the communities' opposition to mega-projects based on their expected environmental and social impacts. The study highlights recent experiences of energy generation mega-projects in terms of addressing aspects of sustainability. Based on these experiences, it discusses underdeveloped role of environmental evaluations and the main regulatory challenges ahead, recommending then public policies to effectively address these challenges.
\end{abstract}

Keywords: energy mega-projects; Chile; environmental evaluation; sustainability

\section{Introduction}

Chile, over the last 26 years, has rapidly progressed on the basis of economic freedom, democracy, and rule of law. As a result, Chile joined the OECD in 2010, as the second Latin American country being accepted after Mexico in 1994. In this context, the country's energy sector went through dramatic changes in the 1980s when the state-owned companies in the electric sector were privatized. The focus was on a private-sector-led growth strategy, which was actually very successful in terms of increasing capacity and improving the efficiency of the firms [1,2]. However, Chile's pioneering experience with the power sector privatization and liberalization created competition problems due to insufficient regulation, especially in transmission, and foreclosure in generation due to the vertical integration of incumbents [2-4].

The adoption of free market economic policies and several institutional reforms allowed the country to achieve an exceptional economic performance with high growth rates, low inflation, and a significant poverty reduction. The significant improvement in the welfare of the population has led to a double boost in electricity demand, positioning Chile as the country with the highest energy consumption per capita in Latin America. However, despite the economic achievements, power supply lagged to keep pace with economic growth. As a consequence, the country experienced several energy crises, some of them as a result of a critical lack of diversified energy sources and investment in the sector. For a fast developing economy, which also has a strong dependence on external sources to supply its primary energy needs, the lack of investment in generation capacity became a critical issue in terms of securing power supply. 
In the country historical unsolved problems related to social, indigenous, and environmental fragilities also exist $[5,6]$, which combined with the marginalization of the communities where energy projects are located has been a potentially significant threat for the development of energy projects. This became particularly true when environmental evaluations started to play a relevant role in the approval or rejection of the mega projects and the weakness of the EIA policies and regulations emerged. In practice, over the past years, environmental evaluations of large energy projects have been a constant source of conflict among communities, investors, and the government [7,8]. As a result, several energy projects using different technologies and located in different regions of the country have suffered a long delay in their approval processes, and most of them ended up either rejected or challenged in court due to a weak and flawed environmental review system. (For example, in the case of HidroAysén, the House of Representatives established a Special Inquiry Commission after the approval of the dam complex, which concluded that the environmental assessment system suffered from failures and weaknesses). In fact, this is true for all of the mega energy projects, such as the Ralco and Pangue dams in the Bio-Bio river (720 MW and 450 MW respectively) in the 1990s, Castilla coal plant (2100 MW) in 2009, the Barrancones coal plant (540 MW) in 2010, and, more recently, the HidroAysén mega-dam complex (2750 MW) in the Patagonia in 2013. (The case of Barrancones is probably the most dramatic one, as the project was approved but to the strong opposition existing in the local community the President of the country called the owners of the project to request them to cancel it anyway and so they did).

One of the key issues to consider is that Chile's high economic growth mostly depends on the exploitation of natural resources, which accounts for $75 \%$ of overall exports. Therefore, policy decisions on the exploitation of natural resources gave high priority to investment and economic growth, while environmental and social concerns were perceived mainly as a restraining factor [9]. Furthermore, energy was an issue in which citizens had no say, as it was related to technical decisions made by experts [8]. The evidence shows that, as a consequence, Chile's economic policies caused significant social and ecological costs affecting the biodiversity in its territory. As a result, increasing environmental concerns and more ambitious social objectives have questioned the long-term sustainability of this pattern of economic development and have increasingly turned energy into an issue that is hotly raises debated or leads to conflict.

This article assesses the energy security and energy-related environmental problems in Chile, focusing on the underdeveloped role of environmental evaluations and the existing deficiencies in policy-making as the main adverse challenges faced by the energy mega-projects. It also gives important policy recommendations for effectively addressing these challenges. The remainder of the article is organized as follows. Section 2 presents an overview of the main controversial energy megaprojects over the last decades. Then, the main existing development trends of environmental policymaking in Chile are highlighted in Section 3. Section 4 examines the key policy challenges faced by large energy projects in Chile, and finally Section 5 discusses policy recommendations.

\section{Controversial Mega-Energy Projects in Chile}

For the last couple of decades, Chile has faced the challenge of balancing its increasing need of securing sources of energy supply to fuel its booming economy, with the also growing environmental concerns in the country. In addition, between mid-2000s and 2015, electricity prices remained high. This is the result, among other things, by the lack of investment in new energy projects caused by the difficulties experienced in obtaining environmental approval for their construction, which is mainly explained by the public opposition to the projects [10]. In this context, large energy projects have been controversial and provoked not only heated debates but also large-scale protests. Table 1 summarizes the relevant information for the four energy mega-projects that have been the most polemic, generating a highly visible public debate and large community protests. The description of each project provides an overview of controversial issues and discusses the implications for the sustainable development of Chile. 
Table 1. Energy Mega-Projects in Chile.

\begin{tabular}{cccccc}
\hline Project & Technology & Capacity (MW) & Flooded Area (Ha) & EIA Presented & EIA Approved \\
\hline Pangue & Hydropower & 450 & 500 & - & - \\
Ralco & Hydropower & 692 & 3500 & March 1996 & June 1997 \\
HidroAysén & Hydropower & 2750 & 5910 & August 2008 & May 2011 \\
Barrancones & Coal & 540 & - & December 2007 & September 2010 \\
Castilla & Coal & 2100 & - & December 2008 & - \\
\hline
\end{tabular}

* The Pangue project started before the enactement of the Environmental Framework Law, so it was not part of the EIA.

\subsection{Controversial Mega Energy Projects: Large Hydropower Plants}

Hydropower is the most technically mature and cost-competitive renewable energy source. It provides a significant share of electricity production worldwide contributing to more than $16 \%$ of electricity generation, most of which comes from large hydro dams that are greater than $10 \mathrm{MW}$ [11]. Nowadays the contribution of hydropower in the energy matrix of Chile accounts for around $30 \%$. However, its magnitude is small given that Chile has a potential hydro capacity that could meet the total electricity demand of the country [12].

Regarding the implications for sustainability, large hydropower plants have both advantages and disadvantages. In terms of advantages, hydropower plays an important role in overcoming energy security concerns as it uses domestic resources, which makes it less subject to price volatility unlike imported energy sources; it possesses long life span, around 50-100 years compared with other forms of electric power generation; it provides important resources in ensuring grid reliability [13]; and finally, it requires less annual operation and maintenance cost ( $1 \%$ of the investment cost) [14]. In addition, large hydropower has some positive environmental effects in reducing emissions GHGs and other major air pollutants. In term of disadvantages, there is no question that the mega hydro projects have significant irreversible impacts on the local communities and the eco-system of the geographic areas where they are located. The most controversial aspects of mega hydro projects include serious environmental consequences on livelihoods and ecosystems together with the resettlement of local populations.

\subsubsection{Ralco and Pangue Hydro Projects}

The first mega-project facing a large public opposition in Chile and involved in controversy was the Ralco and Pangue dams in the Bio-Bio River. In 1965, Endesa-the main electricity generator in Chile at that time and a state-owned firm-announced a plan to develop six large dams on the Bio-Bio River in southern Chile (the potential in the basin being 2900 MW). Then, in 1990 Endesa, now a private firm, announced the plan to build the Pangue Dam, the first one of the six identified in 1965. Endesa presented the construction of their hydro projects as an issue of national security for meeting the energy demands of Chile's growing economy. Pangue hydroelectricity dam has a capacity of $467 \mathrm{MW}$ generated by two Francis turbines with a nominal flow of $250 \mathrm{~m}^{3} / \mathrm{s}$ each. The project was the first dam completed on the upstream of the confluence of the Bio-Bio River, which is home for Pehuenches, one of the branches of the Mapuche people, the largest ethnic group in Chile. Besides, the eco-system connected to the Bio-Bio River is quite fragile; therefore, the numerous unique plant and animal species are dependent upon the river for their survival. Because of the potential for significant environmental impacts and social effects on the local Pehuenche people, the projects had considerable controversy not only in Chile but also worldwide.

For the purpose of construction of Pangue, Endesa requested funding support from the International Finance Corporation (IFC), an agency of the World Bank. The EIA of the project formed part of IFC's appraisal and was contracted to a US consulting firm. The study addressed not only environmental impacts but also the issues of resettlement of indigenous Pehuenche people and others affected by the 500 ha reservoir. The Pangue project was designated Category A by the 
IFC, which means the project has serious issues of environmental and social concerns. The loan agreement explicitly considered environmental protection and some mitigation measures, including the acquisition of land for the relocation of indigenous people to be displaced. In 1995, due to the strong opposition to the project by indigenous communities, the IFC contracted a study to review their implementation. Once the report was submitted, Endesa did not grant permission for its release, which generated the view that its conclusions were negative and that it could be even put at risk Ralco, the next project to be implemented in the area. As a consequence, the IFC threatened to declare Endesa in violation of the environmental conditions of the loan agreement, Endesa threatened to sue the IFC if the report was released and, finally, decided to buy out the IFC loan $[15,16]$. The involvement of the IFC had been very relevant, as the Pangue project was implemented before Chile enacted environmental laws and, therefore, the IFC provided some minimum international standard for the environmental evaluation of the project [16]. This turned out not to be the case and, in a period of time in which Chile faced the risk of energy rationing, the project was approved without significant objections.

In the case of Ralco the legal and regulatory conditions were different. Ralco is located upstream of Pangue reservoir generating $692 \mathrm{MW}$ at the design discharge of $368 \mathrm{~m}^{3} / \mathrm{s}$ and it also has two large, equally-sized Francis turbines. At the time of its implementation, the Chilean Parliament had ratified the Indigenous Peoples Law in 1993, enacted the Environmental Framework Law in 1994, and the mandated EIA was legally in place. However, because the environmental legislation was quite new and the institutions implementing it somehow weak, the project was approved without requesting the relevant and necessary environmental studies and with few mitigation measures and ex-post monitoring of its impacts [17]. In particular, the implementation of EIA was conducted through irregular procedures [16]. In spite of all these irregularities and a strong opposition, both projects-Ralco y Pangue were approved and implemented with strong government support $[6,16]$. Pangue started operating in 1996 and Ralco in 2004.

In terms of compensation for the affected communities, it might be relevant to mention that in 2002 five Pehuenche women brought the Ralco case to the Inter-American Commission on Human Rights. This resulted in an agreement with the Chilean Government under which individual compensation was granted to the petitioners.

\subsubsection{HydroAysén Hydropower Project}

Among the most controversial mega projects, which generated extended conflicts with local communities and environmentalists, HidroAysén has probably been the most notorious one. The project intended to build five hydroelectric power plants on rivers of the Aysén Region in the Patagonia. The plants were planned for an installed capacity of 2750 megawatts, corresponding to $13 \%$ of the country's total installed capacity as of 2016. This mega project was supposed to play an important role in overcoming energy security concerns of the country, contributing to reduce the foreign fuel dependency in large volume. In addition, the construction of the project would provide an important economic contribution to the local population of the region. However, the project required flooding a total of 5910 hectares of land, some fraction of them has agricultural use and a large fraction correspond to protected areas of environmental significance and large eco-friendly touristic potential. In addition, a transmission line of more than $2000 \mathrm{~km}$ long is needed to carry the electricity produced in the Patagonia to the main consumption centers. The line would have to pass through several natural reserves, ancient forests and the natural habitat of protected species. It would also cross several cities and many small towns, including some indigenous communities.

In 2008, the project developers-the two largest electricity generation companies in the country, Endesa and Colbun - presented the EIA study for the 5 power plants before the National Environmental Commission (Conama), the institution handling the environmental evaluation before the Environmental Assessment Service (SEA) was put in place. A first controversial issue had to do with the fact that the EIA study did not include the transmission line (It might seem obvious that the generation and transmission components would have been considered one project for EIA purposes 
given that one would not be built without the other. However, it was argued that Transelec, the firm building and operating the transmission line, was a separate entity from Endesa, and, therefore, should have to present its own EIA for the transmission line project. Conama accepted the idea of a separate EIA to be presented by each entity [15]). After a long process of evaluation, including new studies that were required and several changes to the original project to mitigate its environmental impact, the project was approved in 2011 (After the Regional Environmental Commission approved the project, more than 80,000 people took to the streets in Santiago, while thousands flooded the streets of various cities across the country in subsequent rallies). The approval was legally challenged by several environmental NGOs, Senators and House representatives, but the Supreme Court rejected all the legal complaints ratifying the approval of the project in 2012. However, the owners of the project decided not to pursue the environmental evaluation of the transmission lines claiming that the lack of a national energy policy prevented the development of large and complex projects like HidroAysén. Finally, in 2014, a Committee of Ministers presided by the Minister of Environment changed the previous environmental approval of the project to rejection, claiming for this purpose new evidence of its negative impacts presented by environmental organizations and also the lack of enough mitigation measures, especially towards the relocation of people living in the areas to be flooded. In that way, Chile's government officially cancelled the controversial HidroAysén project.

Similar to the Pangue and Ralco cases, the planning of the HidroAysén project did not consider the involvement or previous participation of all affected parties. Additionally, the project evaluation lacked the necessary cost/benefit analyses including all the potential effects and externalities: economic, social, community-related and environmental. The project also lacked sustainability studies as part of the project decision-making with the purpose of reviewing all the potential impacts of the dam, such as addressing the potential longer-term impacts on the eco-tourism, the possible displacement or out-migration of residents, and the disturbance of fish spawning areas, wetlands and Patagonian fauna (condors, guanacos and pumas). Project opponents argued that a detailed analysis of alternative energy sources in Chile such as solar, wind, geothermal and tidal wave were completely ignored in the project decision-making.

\subsection{Controversial Mega Energy Projects: Large Coal-Fired Power Plants}

Coal is the most widely available fossil fuel resource, satisfying more than $40 \%$ of the world electricity needs. Coal-fired power plants play a major role in supporting the development of large-scale base-load electricity in an affordable and secure way. For that reason, coal has been also, and still being considered to be one of the key elements of Chile's energy security strategy. Although the country owns significant reserves of bituminous coal, due to its high exploitation costs the government was forced to close the mines and shift from local production to imports. In 2016, coal accounted for $22 \%$ of the total electricity generation in Chile, $95 \%$ of it imported from Colombia, Indonesia and Australia. Although coal provides both technical and economic stability to the Chilean electricity system and its role in the technology mix had been growing, investments in coal generation face adverse challenges. Regarding meeting environmental objectives, coal-fired power plants have the highest GHG emission intensities on a lifecycle basis. Today, energy production and consumption constitutes the largest part of all emissions in Chile, accounting for $75 \%$ of the total GHG emissions and obviously, the contribution of carbon-intensive plants remains very significant.

\subsubsection{Barrancones Thermal Power Plant}

A good example of controversies related to a thermal energy mega-project is the one experienced by the project called "Barrancones". In December 2007, the consortium GDF Suez presented for its environmental evaluation a project for developing a thermal power plant in the area of Barrancones. The project location was $25 \mathrm{~km}$ from a marine reserve where $80 \%$ of the world's Humbolt penguins live. In August 2010, the Environmental Regional Commission (ERC) approved the project. As a result, thousands of people protested in front of the Presidential Palace in Santiago. Two days later, 
the President announced that the project would not be built after a conversation he had with the owners of GDF Suez asking them to change the location of the project (The president did not have any institutional power to stop the project. Therefore, what he did to solve the conflict between the official environmental approval and the rejection of the community is something that puts at risk the role of participation [18]). Indeed, one day after the presidential announcement, GDF Suez announce that they would not go forward with the project. Then, in November 2010 they officially withdrew the project, which was accepted by the ERC. It is not known what arguments the President used to convince GDF Suez for not building the project. All the available information is based on the official statement of the President and the one of GDF Suez. The President said that he was respectful of the environment and that he had announced while campaigning that he would oppose the construction of a thermoelectric plant in that area and, therefore, what he had done was coherent with what he had promised. The statement of GDF Suez said that the project had fulfilled all the environmental standards in Chile and also in the European Union, but that they were respectful of the decisions of the authorities in Chile and that the country should start a national discussion about the energy sources they would use to provide energy in the future.

\subsubsection{Castilla Coal-Fired Project}

Finally, a mega-project worth mentioning is the Castilla Complex near Copiapó City, the largest coal firing plant project ever in Chile. In 2008, the Brazilian company MPX presented for environmental evaluation before the SEIA the EIS for the project Castilla, the largest coal-firing plant in all South America, with six $350 \mathrm{MW}$ pulverized coal units. The project also included a 125 ha cinder disposal site and a port to get the coal from overseas. In 2009, the first set of objections arose from several groups-regional public institutions, NGOs, and organized communities-that closely scrutinized the project and filed complaints based on its environmental impacts and the fact that the port had been presented as a separate project to be evaluated independently from the coal-firing plant, all of which resulted in the first rounds of protests against the project. In 2010, based on the report from the Atacama Regional Health Secretary (ARHS), the ERC qualified the project as "polluting", which prevented the project to be built in the proposed location. MPX tried to reverse this qualification appealing it before the ARHS and the ERC. The ERC rejected the appeal, but Conama, which has the final decision, decided to stop processing the environmental evaluation until the ARHS decided on the appeal. Meanwhile, in the Atacama Region, the project added new opponents and people started getting uneasy regarding how the decisions are taken in Chile's Capital Santiago, without considering the region's will. During 2010, the number of groups within the region that expressed their rejection to the project grew consistently to include Municipalities, the farmers from Totoral (neighbors to the project) and most of their regional council members. In May 2010, the ARHS decided to change the qualification of the project from "polluting" to "disturbing", which allowed the project to be developed and built in the proposed location offering mitigation measures. In July 2010, a community organization filed a complaint before the Court of Appeal to change the nature of the project back to polluting and in September 2010, the Court affirmed the original decision by the ERC and upheld the polluting nature of the project. In November 2010, the Supreme Court of Chile ratified the sentence from the Court of Appeal, making the approval of the project almost impossible. The company finally abandoned it.

\section{The Legal and Regulatory Framework for Environmental Evaluations in Chile}

Since the early 1970s, there has been a worldwide expansion of environmental protection standards through different legal frameworks and procedures directly concerned with environmental protection and management. As a result of the globalization, environmental governance practices have also been undergoing major transformations $[19,20]$ and the effect of environmental measures on market access negotiations for international agreements has become particularly important. Therefore, in order to participate in international agreements and obtain the benefits of free trade and investment 
liberalization, the environmental protection standards of each country required to be well integrated into national and international policy frameworks. In this context, Latin American countries faced increasing pressure from internal and external forces to adopt higher environmental protection standards. However, environmental policy making in most of the region has been constrained by institutional and political arrangements and, in practice, environmental legislation has only progressed when the internal demand has been strongly allied with global forces [21]. As other countries in the region, Chile faced a serious challenge in terms of environmental stewardship under conditions of rapidly increasing investment in natural resource industries. Through many decades, although environmental and its associated public health concerns within the civil society were evident, environmental policy planning and regulation in Chile were considered as a detrimental factor to economic growth. Environmental rights in the 1980s constitution were ambiguous and very limited, especially when compared to private property and economic rights. By early 1990s with the return to democracy, many internal factors-including an accumulation of severe environmental problems and the emergence of environmental NGOs-put enough pressure on the government to undertake environmental reforms. However, according to many scholars, a policy window for stronger environmental standards and regulations in Chile was not open until these internal factors were linked with foreign pressures [22,23], including the country's accession to the OECD in 2010. Environmental protection policies were first implemented in 1994, when the Environment Law (No. 19.300) was enacted. The law aimed to establish a single environmental regulatory system and, for that purpose, incorporated explicit procedures for assessing environmental impacts, giving priority to the Environmental Impact Assessment System (SEIA) as the principal tool for environmental impact evaluation. In 2010, Congress approved a new law (Law No. 20.417) that made several amendments to the Environmental Law. The changes introduced implied a significant progress towards establishing a modern environmental institutional system.

\subsection{Institutional Framework}

Under the first Environmental Law (No. 19.300) in 1994, the Conama was a coordinating body of all the environmental policies of the state and, as such, was in charge of the SEIA process in Chile. The role of Conama comprised proposing policies and environmental regulations, managing the SEIA, and to impose penalties when noncompliance with established requirements occurred. Compared to the supervisory bodies existing in most countries of the region, this was the environmental regulatory institution with the lowest hierarchical status responsible for leading environmental policies. Conama's environmental objectives were often opposed by productive and development goals promoted by other ministries within the government. This was not only because Conama lacked political weight, but also because it did not have an adequate division among its environmental regulation, enforcement, and productive development functions. As a result, Conama was never able to implement an effective inter-sectorial coordination.

The 2010 Environmental Law abolished Conama and introduced three main regulatory institutions together with some less substantive institutional amendments. These institutions are the Ministry of Environment (MMA), the SEA agency (Santiago, Chile), and the Environmental Superintendence (SMA) (Table 2). The MMA has a broader and larger scope than what Conama had and is a responsible body for designing and applying environmental policy, plans and programs in Chile. The SEA is in charge of managing the SEIA process, evaluating the impact of all development and infrastructure projects in the country, and also has the role of promoting and facilitating public participation within the project evaluation process. The SMA is an independent and autonomous tribunal, responsible for executing, organizing, and coordinating the compliance and enforcement with respect to project activities. The 2010 Environmental Law also instituted the Council of Ministers for Sustainability, which is chaired by the Minister of Environment and its responsibility is to advise the President in the areas of environmental protection, protection of natural resources, and the evaluation of the environmental impact of economic activities. 
In 2012, a new Law (No.20.600) was enacted to create the Environmental Courts with the role of conducting judicial reviews of the decisions of the Environmental Superintendent and to resolve administrative controversies and demands related to environmental damages.

Table 2. Current Environmental Institutional Framework in Chile.

\begin{tabular}{cl}
\hline Institution & \multicolumn{1}{c}{ Main Responsibilities } \\
\hline $\begin{array}{c}\text { The Environmental } \\
\text { Ministry }\end{array}$ & $\begin{array}{l}\text { Setting the policies, plans and programs related to environmental issues, promoting } \\
\text { sustainable development, and the integrity of the environmental policy and its regulations. }\end{array}$ \\
\hline $\begin{array}{c}\text { Service of Environmental } \\
\text { Assessment }\end{array}$ & Administering the Environmental Impact Evaluation System. \\
\hline $\begin{array}{c}\text { Superintendence of the } \\
\text { Environment }\end{array}$ & $\begin{array}{l}\text { Running environmental inspections and penalizing in cases of } \\
\text { environmental non-compliance. }\end{array}$ \\
\hline $\begin{array}{c}\text { Council of Ministers for } \\
\text { Sustainability }\end{array}$ & $\begin{array}{l}\text { Chaired by the Minister of Environment, advises the president on sectorial policies, } \\
\text { including drafting laws and regulations about the environment. }\end{array}$ \\
\hline Environmental Courts & $\begin{array}{l}\text { Specialized jurisdictional bodies whose function is to solve environmental controversies } \\
\text { under their competence and ruling on other topics mandated by law. }\end{array}$ \\
\hline
\end{tabular}

\subsection{Environmental Impact Assessment (EIA) in Chile}

The EIA has increasingly become a routine decision making technique on environmental evaluations and has been implemented extensively in the world. As it is well known, the EIA is an effective planning and management tool for identifying the impact of a specific activity, project or even policy, regarding its magnitude and potential effects on the environment. The EIA was first adopted in 1969 by the United States government as part of the National Environmental Policy Act. Since the 1980s, its application has expanded worldwide, initially in the European Union and OECD countries and then, under the pressure of the leading countries, toward international organizations that expanded its environmental capacities [24]. The Rio Earth Summit Conference in 1992 recommended the implementation of EIAs, which had a strong influence in many-until then-reluctant developing countries [25,26]. (The environmental impact assessment was officially recognized as a tool for informed decision-making towards sustainable development (Principle 17, Rio Declaration) and for protection of biodiversity (Article 14, Convention on Biological Diversity)). Today, most South American countries have incorporated some type of EIA system in their environmental legal and regulatory framework.

In Chile, as described before, the SEIA was introduced in 1994 as the principal tool for environmental impact evaluation. The Environment Law establishes that the projects or activities that are likely to produce environmental impact, in any of their stages, are subject to a mandatory assessment of their environmental impact (Table 3 summarizes the EIA process). In the case of energy projects, the SEIA process is mandatory when a project's installed capacity is larger than $3 \mathrm{MW}$, regardless of the type of resource to be exploited and whether the project requires or not the construction of high-voltage electric transmission lines and substations. Even though the main goal of the process is to guarantee that a project neither produces damage nor does it represent a hazard to the environment, the SEIA also considers and evaluates its social impacts. For projects and activities that are not subject to the SEIA, a relevant sector-specific government agency is responsible for enforcing environmental regulations. If a project is subject to the SEIA, the environmental evaluation must follow one of the two-submission routes to start the process. The first route is to file an Environmental Impact Declaration (DIA), which is a simplified procedure applicable to those projects that do not generate any of the environmental impacts explicitly indicated in the Environmental Law. The second route, considered for projects generating the environmental impact criteria stated in the law, requires filing an Environmental Impact Study (EIS), which is more complex and demanding. The law lays down six environmental criteria for deciding which route to take. The criteria are (1) risk to public health; (2) significant adverse effects on quantity and quality of renewable natural resources; (3) relocation of 
human communities; (4) proximity to the population, protected resources and areas; (5) alteration of cultural heritage, and (6) alteration of the landscape. If any aspects of the project generate at least one of the impacts above, an EIS must be presented, otherwise the developer chooses whether to present a DIA or an EIS.

The DIA is a sworn statement declaring that the project fulfills the environmental law, which must be presented together with all the relevant information, allowing authorities to evaluate if the project actually satisfy the environmental regulations. More specifically, the DIA requires documentation: explaining the project in detail; justifying why to present a EIS is not necessary; explaining in detail how the project will comply with the relevant environmental regulations; and a list of all required permission necessary to build and operate the project together with the relevant information showing that the project will fulfill the requirements to obtain them.

The EIS requires to present detailed information on: a description of the project; an environmental baseline, including all other project approved within the same relevant geographic area, even if they are not operating yet; a reasonable prediction and evaluation of all environmental impacts, including all potential risks; all actions necessary to reduce the impacts and risks and also the mitigation measures to be adopted; a plan for a follow up of all the relevant environmental variables that originated the EIS; and plan to fulfill all environmental regulations.

Once the DIA or EIS is submitted to the SEIA for review, it is evaluated and then the project receives approval, objections to be amended or rejection. The final decision-called environmental qualification resolution (Resolución de Calificación Ambiental, RCA)—is taken by a committee composed of the Regional Governor, the Regional Director of the SEA, and regional representatives of several ministries. In addition, the Law mandates that the State must ensure minimum mechanisms for citizen participation in matters dealing with the EIS procedure. The regulation of these minimum mechanisms indicates that the applicant must publish a summary of the study in the local newspaper containing the project's essential data and must transmit it by local radio broadcasts at its own expense. The public whether directly affected by the project or not, can review the project and submit comments and observations to the relevant agency within 60 days of publication. It is important to mention that the term "public" is not specifically defined in the Law as it just says "citizens". In the case of an EIS, any individual or legal entity can participate and raise observations. However, there is a limitation in the case of a DIA as observations can only be presented either by NGOs representing the local community or a group of at least 10 individuals directly affected by the project.

Table 3. Summary of EIA process in Chile.

\begin{tabular}{cl}
\hline \multicolumn{1}{c}{ EIA Process } & \\
\hline Decision-making authorities & $\begin{array}{l}\text { ME: Ministry of Environment; Environmental Assessment Service (EAS); } \\
\text { Environmental Superintendency (SMA). }\end{array}$ \\
\hline \multirow{2}{*}{ Screening } & $\begin{array}{l}\text { The list of project types is determined by Law. It is related to those projects with } \\
\text { the potential for creating significant risks to human health or cause significant } \\
\text { impact on natural resources, resettlement, or communities' livelihoods; otherwise, } \\
\text { only a DIA is needed. }\end{array}$ \\
\hline \multirow{2}{*}{ Scoping } & $\begin{array}{l}\text { No formal provision. Minimum scope, specified in legislation is based on six } \\
\text { criteria which includes analysis of potential impacts on human health, natural } \\
\text { resources, social conditions, protected areas, and landscapes; and on cultural, } \\
\text { archaeological, and historical heritage. }\end{array}$ \\
\hline \multirow{2}{*}{ Public participation } & Environmental Law mandates citizen participation. \\
\cline { 2 - 3 } Monitoring & Citizens can submit comments on EIS up to 60 days after presented. \\
\hline Reporting & $\begin{array}{l}\text { EIA should include an Environmental Monitoring Indicator Plan in accordance } \\
\text { with the general instructions issued by the Environmental Superintendence } \\
\text { (SMA). It should also include the period and frequency for the delivery of reports } \\
\text { evaluating the results. }\end{array}$ \\
\hline $\begin{array}{l}\text { The SMA controls the ongoing compliance with the conditions, rules, and } \\
\text { measures set out in the Environmental Qualification Resolution (RCA). }\end{array}$ \\
\hline
\end{tabular}




\section{The Challenges Faced in Practice}

During the last decade, Chile achieved a remarkable progress in terms of environmental regulation through consolidating its environmental institutions and designing a comprehensive environmental policy framework. As a result, now environmental and social impact evaluation of each project is explicitly required by law. However, the benefits of environmental reforms are lagging behind since there exists a lack of effective policy implementation and law enforcement [27]. Still today, the implementation of the existing environmental framework in Chile does not provide adequate opportunities to address the trade-offs associated with a sustainable use of natural resources [17].

In fact, the case studies of Pangue/Ralco, HidroAysén, Barrancones, and Castilla projects provide an overview of the controversial issues related to hydroelectric dams and coal plants that provoked intense public debates and large-scale community protests in Chile. The bitter struggles over these projects illustrate the lack of effectiveness in policy-making to solve the country's energy problems while considering the social and environmental impacts at local levels.

Therefore, environmental and energy policy-making in Chile did not provide adequate opportunities to address the trade-offs associated with a sustainable use of natural resources. Besides, the implementation of EIA studies in all described projects failed in many aspects or they were conducted through an irregular procedure. The environmental evaluation system ultimately failed to truly justify and guarantee that large energy projects do not generate serious environmental impacts, even though some of them were initially approved by the environmental authorities. Thus, the government failed to adequately balance environmental protection and economic growth [28]. As a result of this institutional failure, several energy projects-especially the large ones-have caused intense public debate reflecting a significant clash between the necessary energy generation investments and the protection, preservation and sustainability of natural resources and the quality of the environment $[3,6]$. Thus, public protests became quite common causing a significant delay or even the halt of HidroAysén, Barrancones and Castilla projects.

The controversies around these projects provide determined the key challenges of environmental policymaking in Chile that adversely affected the realization of large energy projects. Chile needs to balance the gains and losses of energy mega-projects within an integrated energy and environmental management policy. The challenges are classified under three broad topics: deficiencies in the energy and environmental policymaking, deficiencies associated with EIA process, and deficiencies in the public participation procedure.

\subsection{Deficiencies in Chilean Policymaking}

The underlying conflict between environmental protection and economic development, even though mostly implicit, has been a real one and became more explicit in the case of energy mega-projects [9]. The failure of these projects has illustrated that they were not framed within long-term analysis of Chile's energy needs and sustainable energy and environmental management strategies. There exists a generalized perception, and some evidence to back it up, that environmental evaluations in Chile have been dominated by economic and political interests, operating more as an instrument of several interest groups influence and rent seeking than as an effective tool to prevent environmental damage from investment projects [22,29-31], for example, argued that many of the problems arising from mega-projects are mostly the result of significant deficiencies in the policy-making related to its limited environmental and sustainability perspectives.

Until very recently, Chile lacked a medium and long-term energy policy that incorporates sustainability objectives (energy, environmental and socio-economic goals) into national planning. The sector was historically dominated by a handful of energy companies with significant political influence, which was used to preserve the status quo in terms of energy policy. Therefore, investment decisions were based only on short-term economic profitability, including several times preventing the entry of new competitors. As a result, decisions on how, when and where energy projects should be developed and constructed, as well as the type of fuel and technology that should be used, were 
dictated only by the private sector. The nature and location of the projects were not the subject of an ex ante-discussion including national or regional planning.

The country lacks a clear and comprehensive sustainable development policy for regions that host mega energy projects and the local communities affected by them. Chile is one of the most centralized countries in South American and the decision-making and implementation for most public policies are taken at the national level and regional and local interests are extensively ignored. This fact, together with poor regional development strategies, prevents a balanced assessment of social, environmental and economic regional aspects for each project. As a matter of fact, in the EIA process, there is no requirement for the proposed project to be compatible with local/regional development policies or plans. The practical application of an EIA to territorial development plans and the implementation of relevant mitigation measures is very limited. The Minister for the Environment is responsible for recommending national environmental standards, but it is difficult to ensure that these national standards are met at the regional level taking into account the existing geographic heterogeneity in many environmental aspects. Moreover, municipalities in Chile have very limitedly powers to go beyond national environmental standards to take into account local environmental conditions, a practice that exists and is quite common in many developed countries.

\subsection{Deficiencies with Environmental Evaluation System, EIA Process}

In the case of the all mega projects described above, there is significant evidence that several components of the environmental impact assessment were incorrectly assessed or failed to fully consider the social and environmental impact of the projects. One particular serious deficiency in the EIA process is the lack of in depth analysis and understanding of scientific evaluations. The cases previously mentioned of large energy projects show that science has not played the relevant role it should in the decision-making related to environmental evaluations and either political or interest groups pressure has sometimes replaced it. For example, in the HydroAysén case, the EIA failed to adequately address significant concerns on measuring the ecosystem, the scope of the hydrologic data was incomplete, and the methodologies used for data gathering and extrapolation are extensively questionable. In the case of Pangue and Ralco, Nelson [15] states that "The inertia and the reactive, rather than proactive, stance shown by the government on energy (specially in hydroelectricity, as is evident from the foregoing discussion) must be attributed to a combination of politics, reticence of bureaucrats to be held accountable or to become involved with anything potentially conflictive, and the very real power wielded by Endesa."

In the part, the problem in the handling of these large energy projects is due to the fact that in Chile there has been overreliance on consultants compared to academic scientists [32]. One of the consequences, besides the potential marginalization of scientific evidence, is that it is generally believed that hired consultants are usually beholden to their employers and will not generate studies with results and conclusions that against their interest. The objective in those cases is not to evaluate the projects, but instead justify them to obtain the EIA approval. Thus, for example, the accountability between the consultant results and possible environmental damages was considered weak in the HydroAysén project [22]. Furthermore, in Chile, consultants used to have important political connections. In fact, several consulting companies were established by politically influential individuals who were previously involved in designing or implementing the environmental politics of the country [33]. In the case of Barrancones, the environmental impact study of the project was performed by the company that owned the project. That is, GDF Suez prepared the study of its own project, through its specialist consultants, without any intervention from autonomous bodies. Consequently, by definition, this study cannot be independent of the company's interests [34].

Another widely perceived problems in the EIA process affecting the realization of energy projects is its timing. More specifically, in terms of timing, there are two challenges that need to be faced in Chile. The first one is that the EIA takes place too late [35], which potentially causes additional costs to the project that would have been avoidable at an earlier stage. In fact, several times, when 
project developers submit proposals for evaluation, substantial investments decisions about design and mitigation measures have already been made and cannot always be changed. Ideally, the EIA process should be able to screen out environmentally unfriendly projects before irreversible or costly decisions are made [17]. The second challenge related to timing is that the whole EIA process might take a long period of time, which causes uncertainty and some additional costs, at least financially. Some delays are every now and then just for political reasons, for example, because it is unpopular for the government to approved a project that-even if it is technically and environmentally sound-has faced public protests. The option then might be to leave the decision to the next government. As mentioned by Spoerer [18], there is no correlation between technical reports and the decision of approving or rejecting a project. The decision is a political one and, therefore, government officials might sign a technical report questioning a project and then voting in favor of approving it, as it was shown in the case of Barrancones.

\subsection{The Lack of Open and Transparent Debate Prior to Project Submissions}

According to Fitzpatrick and Sinclair [36], public participation "accentuates the effectiveness of the environmental assessment, actualizes the principles of democracy, ensures that the project meets the needs of the public, assigns legitimacy to a project, provides awareness for conflict resolution for stakeholders, provides a forum for the submission and inclusion of local knowledge in the EA decision, and provides for a more comprehensive consideration of factors on which decisions are made". Analysis of the Barrancones, HydroAysén, Pangue/Ralco and Castilla projects shows that there has been a lack of transparency in the dialogue between the different stakeholders involved: citizens, developers, owners of the projects, and government. For example, the existing provisions for public participation in the Chilean EIA do not guarantee an adequate consideration of project alternatives or the minimization of potential environmental impacts, which has led to environmental and social conflicts in the large energy projects. This lack of open and transparent debate prior to projects limited the possibility of having a posterior reasonable public discussion. One of the main challenges in terms of public participation, is to generate legitimacy with respect to the decisions made under the EAI process. As stated by Berdegué and Reeves [37], the lack of legitimacy of the evaluation process does not provide an effective space for discussion; additionally, the distribution of costs and benefits for affected communities is inadequate. The role for the affected communities was quite limited as it was only in terms of helping them to identify impacts that were not considered by the project developer [38]. In practice, citizens received information and they have 60 days to send written observations, which are then considered by the environmental authority but are not a reason to reject the project. For example, in the case of Barrancones there were 650 observations from the affected communities, but they were barely mentioned in the resolution approving the project. In that sense, the participation of the community seems to be just a formality to legitimize the environmental approval of the project, but it is not a real mechanism of participation and decision allowing to incorporate the observations of the community into the project [18].

In most cases, several other factors such as the lack of education, effective citizens' interest in environmental matters, and their difficulty in understanding the scientific-technical language of the projects were a major impediment for effective public involvement. Therefore, the meetings organized with the local population to present them the projects did not seem to be adapted to their sociocultural characteristics: rural, with a low education level. Almost all mega energy projects are situated in isolated rural areas, where the population has lower education levels than in urban areas. Furthermore, they have little knowledge and no training at all in technical, scientific or legal issues and they neither receive any legal and technical counseling from the authorities nor receive any financial aid to hire it. In fact, under the current Environmental Law (No.20.417) [39], citizens' observations within the public participation process should be submitted through Internet only. Certainly, this situation is detrimental to populations in isolated areas where there is no infrastructure, resources and/or knowledge to use such technology [9]. 


\section{Conclusions and Recommendations}

Over the last couple of decades, because of an increasing energy demand, a significant and persistent energy dependence, and the absence of effective long run energy policies to aligned the sector with the national interests the increasing environmental concerns of the population, the country has faced difficult situations in the energy sector. In fact, the country experienced several consecutive energy crises due to deficits in its energy supply, which even led to electricity rationing in some periods. This situation mobilized the government to stimulate rapid investment in the sector with the goal of fostering a more reliable supply and diversifying the country's energy matrix. Nevertheless, growing socio-environmental concerns faced by large traditional energy projects established serious bottlenecks in the sector, especially in terms of attracting new investment. The failure of the large-scale investment projects showed that the country's energy strategy should not only be related to only address the national problem of potentially acute energy shortages and high electricity prices. The energy policy of the country should play a key role as an instrument for balancing the needs of new energy projects in and the goal of reaching a sustainable economic development. However, to be able to play such a role - and prevent social conflicts-the regulatory system requires not only technical capacity and independency, but also legitimacy among the citizens and to be able to consider a sufficient degree of participation of the communities affected by the projects.

After decades of insufficient regulation in the sector, Chile should reset its future energy policy and aligned the new investments with environmental protection and the country's democratic, economic, social and community goals. Based on the important lessons learned over the Pangue/Ralco, HidroAysén, Barrancones and Castilla mega projects, the following recommendations are proposed.

\subsection{Improvement on Environmental Evaluation System}

Regarding the evaluation process, a first step to improve it would be the generation of baseline information on ecological and socioeconomic conditions that can help future project evaluations and also allow monitoring them once they have been approved and later on implemented. A second step would be to consider a more comprehensive environmental evaluation, which includes policies, plans, and programs [40]. The project level EIA reacts to development proposals rather than anticipate them, which prevents to steer development towards environmentally robust areas or at least away from environmentally sensitive areas. Environmental conflicts are related to the location of new projects and also to their potential impact. Even though the SEIA system might help in terms of reducing or preventing these conflicts, the lack of territorial planning limits its role and exacerbates the conflicts [38]. Additionally, the cumulative impacts caused by several projects should be properly considered and more specifically, different parts of a project should never be evaluated separately, like an energy plant and its transmission line or several dams next to each other that are part of the same project development. Finally, a third necessary step is to significantly improve the role of citizen participation. Currently, the public participation period of an EIS is just for 60 business days and it would be useful to have a longer period to allow citizens to get better informed about each project, maybe around 90-100 days, and start before the project is presented for EIA. However, beyond the time span, opportunities for citizens' opinions in the development of a project are very limited, which prevents at an early stage of the project the evaluation of alternatives that would reduce environmental or social negative impacts. Therefore, it is fundamental to develop clear and effective mechanisms for public participation in the EIA processes. The SEIA system should ideally provide social acceptability to complex choices [41]. For these purposes, public participation must start earlier such that the affected communities are able to provide meaningful feedback and even exercise some real influence over the project's design or implementation. It would also be important to consider not only environmental and social concerns, but also a project's impacts on the demographic mix, community and institutional structures, and threats to cultural practices.

Transparent procedures should be put in place so that impacted individuals and communities are appropriately consulted and receive the appropriate compensation for the damages imposed. 
Mitigation measures are mandatory when a DIA or EIS is presented, but there is no regulation about their type, quantification, relationship with the negative externalities caused, and their approval. Additionally, the compensation measures do not require an economic and social analysis. As a result, both are completely arbitrary and the incentives for the project developer are to propose the cheapest measures possible regardless if they fulfill the goals of mitigating or compensating the impacts of the project [38]. It is important to highlight that obtaining effective mitigation measures, instead of just monetary compensations, which has been usually the case, is the best way to obtain legitimacy among communities and a sustainable development in the long run. Additionally, it would be relevant to incorporate requirements for closure plans into EIAs. For example, in South America, Peru has made significant progress in this respect by incorporating it to mitigate long-term environmental impacts that have typically challenged the sustainability of mega energy projects.

Given that several of the conflicts related to large energy projects have occurred in poor areas of the country, it might be necessary to provide a cost-free, neutral and technically sound advice to the communities affected [9] and also to invest in environmental education for the population of communities potentially affected by future projects. In such a way, the communities would be able to actively participate in an informed way and reach a reasonable agreement-in terms of environmental and social impacts and also mitigation measures-for the development and implementation of a large energy megaproject.

\subsection{Improvements on the Institutional Capacity}

Regarding the institutional dimension, Chile has made some progress toward improving the transparency of the EIA system and also diminishing the possibility of political influence. However, it still necessary to increase the regulatory capacity of government authorities to implement the new environmental legislation and process the increasing numbers of EIAs in the system. For this purpose, it is necessary to significantly increase the budget of the EIA system, allowing it to hire more and better personnel, thus increasing its technical capacities. In such a way, it would possible to improve the formulation of predictive techniques and methods to better evaluate the EIAs and then also monitoring the environmental impacts and enforcing the mitigation measures. The main goal for the Chilean government should be to strengthen the legitimacy and technical capacity of the environmental evaluation system, such that the evaluations are closely regulated by the government, but independently evaluated.

\subsection{Implementation of Strategic Environmental Analysis (SEA)}

The establishment of a Strategic Environmental Assessment (SEA) in the new Law is a significant step forward to compensate for all the EIA weaknesses, especially in the case of large projects. The SEA is widely recognized as a promising method to analyze and address the environmental effects of policies, plans, programs and other strategic initiatives. Although relatively new, its implementation has been broadly used, mainly in Europe and North America. As an extension of the aims and principles of an EIA, a SEA applies primarily to higher levels of the decision-making process in cases when there is far greater scope than at the individual project level, allowing to incorporate environmental considerations into development goals and objectives. This is usually the case, for example, when there is greater uncertainty about the effects of a policy, a broader range of environmental consequences, and a wider set of linkages and trade-offs in economic and social issues. In fact, one of the main criticisms of the role played by EIAs in energy mega-projects, was the lack of a more appropriate strategic assessment. For the evaluation of these large projects then, which have strategic consequences related to national energy objectives, a more 'strategic approach' could fit better than an EIA for their analysis. 


\subsection{Studying the Best Examples from Other Countries}

Studying experiences of other countries would have been instructive to prevent some of the adverse consequences and conflicts related to mega energy projects in Chile. Many countries faced similar concerns regarding mega projects, but their solutions were widely different and some lessons from their experiences are valuable. For example, from the Canadian experience, Dusyk [42] examined the importance of participatory processes in the decision-making of the construction of a large hydro dam in British Columbia. She reported how an effective participation can facilitate sociotechnical change by creating opportunities to collectively reframe problems and their solutions.

In Latin America, even though there are mixed results regarding similar issues, there also exist some successful experiences with large projects that could provide useful lessons and guidelines for improving the design and implementation of environmental impact assessments of mega-energy project developments in Chile. For example, the Bolivia-Brazil Gas Pipeline project (GASBOL) has been widely recognized as a model of best practices in environmental management [43]. Despite significant difficulties and challenges in the development of the project, given that the pipeline crosses several environmentally and socially sensitive territories on both countries, the EIA was well implemented. Among the good lessons learned from this project are the continuous monitoring and follow-up of each environmental issue, the rapid response to conflicts, the innovative strategies for protecting fragile ecosystems, the effective dialogue with indigenous communities, and the good compensation measures to those directly affected.

\subsection{Developing a Consistent Compensation Framework}

Environmental compensations or offsets are a necessary and natural mechanism to be considered when a project has adverse impacts on areas of high environmental and social/cultural values. Compensations do not refer only on monetary payments to affected communities, but consider different mitigation measures to reduce the negative impacts of a project, especially the large ones. In Europe and the USA, it is a mechanism used and considered with the objective of recreating the affected ecosystems and minimizing the negative consequences of these projects [23,44]. Chile's current regional planning and EIA processes lack an effective application of such compensation measures, especially in the case of large energy projects. In this respect, the country needs to rethink how it is best to integrate different compensation mechanisms into the existing regional planning and evaluation processes. It is also necessary to improve the existing implementation of those compensations based on the best international practices and cost-reducing approaches.

Author Contributions: Shahriyar Nasirov and Claudio A. Agostini designed and performed the research, reviewed literature, and wrote the paper with results checking. They were responsible for analyzing and interpreting the data. Carlos Silva gave review suggestions, reviewed the literature, and reviewed the entire paper. All authors read and approved the final manuscript.

Conflicts of Interest: The authors declare no conflict of interest.

Funding: The authors disclosed receipt of the following financial support for the research, authorship, and/or publication of this article: This work was funded by the Research Grant CONICYT/FONDAP/15110019.

\section{References}

1. Fischer, R.; Serra, P. Efectos de la Privatización de Servicios Públicos en Chile: Casos Sanitario, Electricidad y Telecomunicaciones; Documento de Trabajo, Centro de Economía Aplicada, Universidad de Chile: Santiago, Chile, 2003.

2. Serra, P. Regulación del Sector Eléctrico Chileno. Rev. Perspect. 2002, 6, 11-43.

3. Bauer, C. Dams and Markets: Rivers and Electric Power in Chile. Nat. Resour. J. 2009, 49, 583.

4. Bitrán, E.; Saavedra, E. Algunos Comentarios en Torno al Rol Regulador y Empresarial del Estado. In Después de las Privatizaciones: Hacia el Estado Regulador; Muñoz, O., Ed.; Cieplan: Santiago, Chile, 1993.

5. Newbold, J. Balancing economic considerations and the rights of indigenous people. The Mapuche People of Chile. Sustain. Dev. 2004, 12, 175-182. [CrossRef] 
6. Susskind, L.; Kausel, T.; Aylwin, J.; Fierman, E. The future of hydropower in Chile. J. Energy Nat. Resour. Law 2014, 32, 425-481. [CrossRef]

7. Barton, C.; Poot, M.J.M.; Crutchfield, Z.; Bloor, P.; Jackson, D. Examining between-year natural variation in seabird numbers and distribution at an offshore wind farm development site. In Proceedings of the BOU Conference Marine Renewables and Birds, Peterborough, UK, 25 November 2012. Available online: https:/ / www.bou.org.uk/bouproc-net/marine-renewables/barton-poster.pdf (accessed on 20 June 2017).

8. Schaeffer, C.; Smits, M. From Matters of Fact to Places of Concern? Energy, Environmental Movements and Place-making in Chile and Thailand. Geoforum 2015, 65, 146-157. [CrossRef]

9. Lostarnau, C.; Oyarzún, J.; Maturana, H.; Soto, G.; Señoret, M.; Soto, M.; Rotting, T.S.; Amezaga, J.M.; Oyarzún, R. Stakeholder Participation within the Public Environmental System in Chile: Major Gaps between Theory and Practice. J. Environ. Manag. 2011, 92, 2470-2478. [CrossRef] [PubMed]

10. Gaete, C.; Gallego, A.; Stamford, L.; Azapagic, A. Towards a Sustainable Electricity System in Chile: Current Situation and Assessment Methodology. In Proceedings of the EES 2015-Multidisciplinary Symposium on Energy, Efficiency and Sustainability, Kassel, Germany, 31 July-1 August 2015; pp. 49-53.

11. International Energy Agency. Global Renewable Energy/Hydropower; International Energy Agency: Paris, France, 2015.

12. Bezerra, B.; Mocarquer, S.; Barroso, L.; Rudnick, H. Expansion Pressure: Energy Challenges in Brazil and Chile. IEEE Power Energy Mag. 2012, 10, 48-58. [CrossRef]

13. Ciocci, L. Hydropower licensing reform: What's all the fuss? Power Eng. 2003, 107, 70-71.

14. Oud, E. The evolving context for hydropower development. Energy Policy 2002, 30, 1215-1223. [CrossRef]

15. Nelson, M. Fifty Years of Hydroelectric Development in Chile: A History of Unlearned Lessons. Water Altern. 2013, 6, 195.

16. Orellana, M. Indigenous Peoples, Energy, and Environmental Justice: The Pangue/Ralco Hydroelectric Project in Chile's Alto Bio-Bio. J. Energy Nat. Resour. Law 2015, 23, 511-528. [CrossRef]

17. Goodwin, P. Induced traffic again. And again. And again. Local Trans. Today 2006, 450, 17.

18. Spoerer, M. Participación Ciudadana e Incidencia Política: Estudio del Caso Barrancones. Rev. Persona Soc. 2013, 27, 17-44.

19. Harvey, D. A Brief History of Neoliberalism; Oxford University Press: Oxford, UK, 2005.

20. Pierre, J. Debating Governance; Oxford University Press: Oxford, UK, 2000.

21. Tecklin, D.; Bauer, C.; Prieto, M. Making environmental law for the market: The emergence, character, and implications of Chile's environmental regime. Environ. Politics 2011, 20, 879-898. [CrossRef]

22. Barandiaran, J. Chile's Environmental Assessments: Contested Knowledge in an Emerging Democracy. Sci. Cult. 2015, 24, 251-275. [CrossRef]

23. Cowell, R. Stretching the limits: environmental compensation, habitat creation and sustainable development. Trans. Inst. Br. Geogr. 1997, 22, 297-306. [CrossRef]

24. Wade, R. The Struggle over the Environment. In The World Bank: Its First Half Century; Brookings Institution Press: Washington, DC, USA, 1997.

25. Hochstetler, K.; Keck, M.E. Greening Brazil: Environmental Activism in State and Society; Duke University Press: Durham, NC, USA, 2007.

26. Kolhoff, A.J.; Driessen, P.P.J.; Runhaar, H.A.C. An analysis framework for characterizing and explaining development of EIA legislation in developing countries-Illustrated for Georgia, Ghana and Yemen. Environ. Impact Assess. Rev. 2013, 38, 1-15. [CrossRef]

27. Nasirov, S.; Agostini, C.; Silva, C. Investors' Perspectives on Barriers to the Deployment of Renewable Energy Sources in Chile. Energies 2015, 8, 3794-3814. [CrossRef]

28. Hervé, D. Las causas del conflicto por la central termoeléctrica de Barrancones en Punta de Choros. Anu. Derecho Público 2011, 1, 189-208.

29. Agostini, C.; Nasirov, S.; Silva, C. Solar PV Planning Toward Sustainable Development in Chile: Challenges and Recommendations. J. Environ. Dev. 2016, 25, 25-46. [CrossRef]

30. Ruthenberg, I.M. Una década de gestión ambiental en Chile. In Environment Department Papers; The World Bank: Washington, DC, USA, 2001.

31. Sabatini, F.; Sepulveda, C.; Bianco, H. Participación Ciudadana para Enfrentar Conflictos Ambientales-Desafios para El Sistema de Evaluación de Impacto Ambiental; Centro de Investigación y Planificación del Medio Ambiente: Santiago, Chile, 2000. 
32. Espinoza, G.; Alzina, V. Review of Environmental Impact Assessment in Selected Countries of Latin America and the Caribbean: Methodology, Results and Trends; Inter-American Development Bank (IDB): Washington, DC, USA, 2001.

33. Silva, E. Democracy, Market Economics, and Environmental Policy in Chile. Lat. Am. Polit. Soc. 1996, 38, 1-33. [CrossRef]

34. Spoerer, M. Paradoxes of Participatory Democracy: Citizen Participation, Collective Action and Political Influence in a Chilean Environmental Conflict. Nuevo Mundo Mundos Nuevos 2014. Available online: http:/ / nuevomundo.revues.org/67153 (accessed on 17 January 2017).

35. De la Maza, C.L. NEPA's influence in developing countries. Environ. Impact Assess. Rev. 2001, 21, 169-179. [CrossRef]

36. Fitzpatrick, P.; Sinclair, A.J. Learning through public involvement in environmental assessment hearings. J. Environ. Manag. 2003, 67, 161-174. [CrossRef]

37. Berdegué, J.A.; Reeves, J.F. Energy for sustainable and inclusive growth-Key lessons for the definition and implementation of SDGs extracted from the Chilean experience. Cent. Latinoam. Desarro. Rural 2015. Available online: http://www.rimisp.org/wp-content/files_mf/files_mf/1426858319Chile_case_study_ policy_lessonsv2.pdf (accessed on 12 January 2017).

38. Costa, E. ¿El SEIA en Crisis? Conflictos Ambientales y Ciudadanía. Derecho Humanid. 2012, 20, 357-374.

39. Biblioteca del Congreso Nacional de Chile. Ley 20417.2010, Santiago, Chile. Available online: http:/ / www. conaf.cl/wp-content/files_mf/1370463403LEY20417.pdf (accessed on 20 June 2017).

40. Alshuwaikhat, H.M. Strategic Environmental Assessment Can Help Solve Environmental Impact Assessment Failures in Developing Countries. Environ. Impact Assess. Rev. 2005, 25, 307-317. [CrossRef]

41. Bronfman, N.C.; Jiménez, R.B.; Arévalo, P.C.; Cifuentes, L.A. Understanding Social Acceptance of Electricity Generation Sources. Energy Policy 2012, 46, 246-252. [CrossRef]

42. Dusyk, N. The Transformative Potential of Participatory Politics: Energy Planning and Emergent Sustainability in British Columbia, Canada. Ph.D. Thesis, The University of British Columbia, Vancouver, BC, Canada, April 2013.

43. Evidences and Lessons from Latin America (ELLA). Improving Environmental Management of Extractives through Environmental Impact Assessments; Evidences and Lessons from Latin America (ELLA): New York, NY, USA, 2013.

44. Eden, S.; Tunstall, S.M.; Tapsell, S.M. Environmental restoration: Environmental management or environmental threat? Area 1999, 31, 151-159. [CrossRef] 